Keywords: Tank Closure, Cooling coil, Tank 5F

Retention: Permanent

\title{
Characterization of Tank 5F Vertical Cooling Coil Leachates for Select Radionuclides-2011
}

L. N. Oji, 773-42A

D. P. Diprete, 773-41A

Issue Date: August 2011

Savannah River National Laboratory

Savannah River Nuclear Solutions, LLC Aiken, SC 29808

Prepared for the U.S. Department of Energy under contract number DE-AC09-08SR22470.

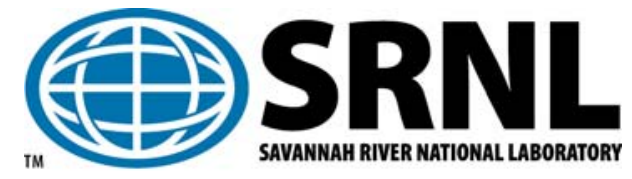




\section{DISCLAIMER}

This work was prepared under an agreement with and funded by the U.S. Government. Neither the U.S. Government or its employees, nor any of its contractors, subcontractors or their employees, makes any express or implied:

1. warranty or assumes any legal liability for the accuracy, completeness, or for the use or results of such use of any information, product, or process disclosed; or

2. representation that such use or results of such use would not infringe privately owned rights; or

3. endorsement or recommendation of any specifically identified commercial product, process, or service.

Any views and opinions of authors expressed in this work do not necessarily state or reflect those of the United States Government, or its contractors, or subcontractors.

\section{Printed in the United States of America}

Prepared for

U.S. Department of Energy 


\section{REVIEWS AND APPROVALS}

AUTHORS:

L. N. Oji, Advanced Characterization and Processing

Date

D. P. DiPrete, Analytical Development

Date

TECHNICAL REVIEW:

S. H. Reboul, Process Technology Programs

Date

APPROVAL:

F. M. Pennebaker, Manager

Date

Advanced Characterization and Processing

S. L. Marra, Manager

Date

E\&CPT Research Programs

R. C. Jolly, Jr.,

Date

Closure Project Engineering

W. B. Dean, Closure \& Disposal Assessment

Date

W. L. Isom, Jr., Manager, Closure Project Engineering

Date 


\section{ACKNOWLEDGMENTS}

The authors express their appreciation to Mary Beasley, Linda Bush and Kevin Reide of the SRNL Shielded Cell Operations for coordinating and performing the acid leaching tests described in this report. The authors would also like to express their appreciation to the SRNL analytical group for their analytical support and input throughout the characterization of the Tank $5 \mathrm{~F}$ cooling coil leachates. 


\section{EXECUTIVE SUMMARY}

Two twenty-four inch samples of vertical sections of the cooling coils from Tank 5F, taken from Riser 1, were made available to SRNL by SRR for leaching and characterization of the leachates for select radionuclide trapped in the corrosion layer on the exterior of the cooling coils. One piece of cooling coil sample was obtained from a section of a vertical cooling coil located above the 45-inch elevation from the tank floor and the other also from a vertical section of a cooling coil located below the 45 -inch elevation from the tank floor of Tank 5F.

Analysis results from both cooling coils show that the predominant radionuclides contributing to the activity in both coils are strontium-90 and cesium-137. The activities for strontium-90 and cesium-137 in the Tank $5 \mathrm{~F}$ vertical cooling coil located above the 45 -inch elevation of the tank and designated as sample 5-R1-A45 averaged 1.34E- $02 \pm 1.12 \mathrm{E}-03$ and 7.27E-04 $\pm 4.46 \mathrm{E}-05 \mathrm{Ci} / \mathrm{ft}^{2}$, respectively, while the activities for the vertical cooling coil located below the 45 -inch elevation of the tank and designated as sample 5-R1-B45 averaged 8.93E-03 $\pm 8.25 \mathrm{E}-04$ for Sr-90 and 8.10E$04 \pm 6.36 \mathrm{E}-05 \mathrm{Ci} / \mathrm{ft}^{2}$ for $\mathrm{Cs}-137$. Other significant activity contributing radionuclides are americium-241 and europium-154/155.

With the exception of the analysis result for Pu-241 in the 5-R1-A45 cooling coils samples, the target detection limits for the other radionuclides were met in both cooling coil samples. The detection limits for Pu-241 analyses result in coil sample 5-R1-A45 were not met consistently because of possible background changes during counting. 


\section{TABLE OF CONTENTS}

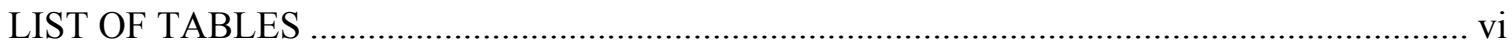

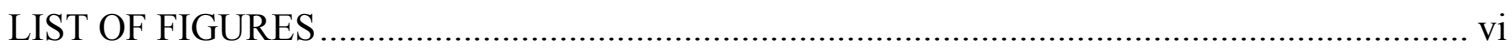

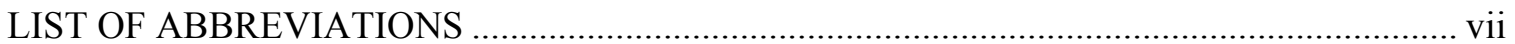

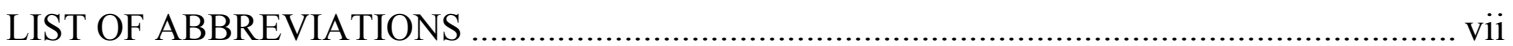

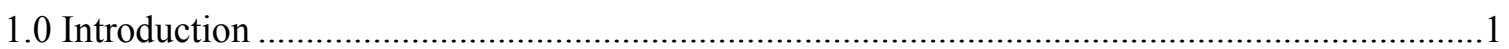

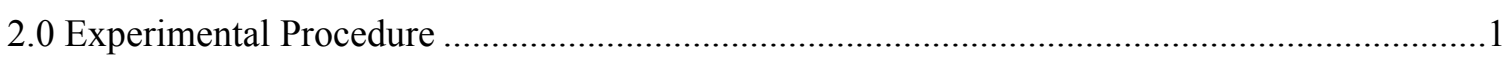

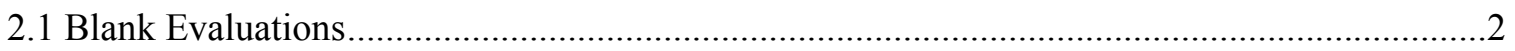

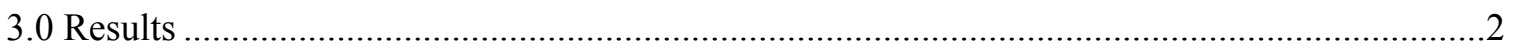

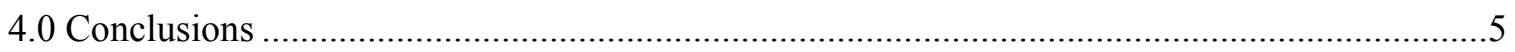

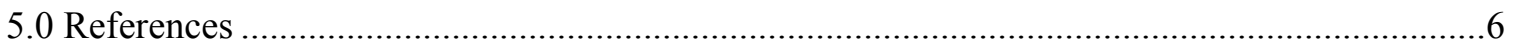

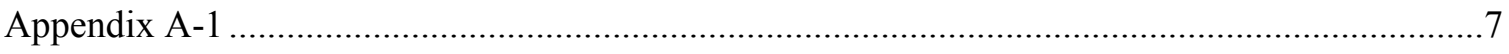

Appendix A-2 …

Appendix A-3 …

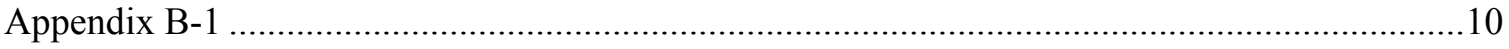

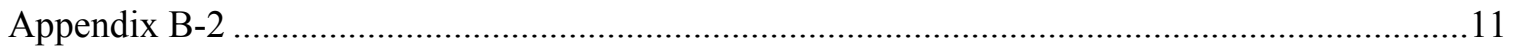

\section{LIST OF TABLES}

Table 1. Radiological Analytes for Tank 5F A45 Cooling Coil (First leach): Coil located above

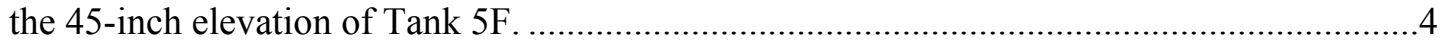

Table 2 Radiological Analytes for Cooling Coil Tank 5F B45 (First leach): Coil located below the 45 -inch elevation of Tank $5 \mathrm{~F}$.

\section{LIST OF FIGURES}

Figure 1. Inserts A and B show pictures of two vertical cooling coils taken from Riser 1 in Tank 5F. Picture was taken inside SRNL shielded cell.

Figure 2 Leaching vessel and a typical leached Tank 5F cooling coil (insert B). 


\section{LIST OF ABBREVIATIONS}

$\begin{array}{ll}\text { SRNL } & \text { Savannah River National Laboratory } \\ \text { SRR } & \text { Savannah River Remediation } \\ \text { AD } & \text { Analytical Development } \\ \text { MDL } & \text { Minimum Detection Limit } \\ \text { UL } & \text { Upper limit }\end{array}$


SRNL-STI-2011-00372, Revision 0

\subsection{Introduction}

Two twenty-four inch samples of vertical sections of the cooling coils from Tank 5F, taken from Riser 1, were made available to SRNL by SRR for leaching and characterization of the leachate for select radionuclide as described in the SRR Technical Task Request (HLE-TTR-2010-004, Rev. 4) and SRNL Task Technical and Quality Assurance Plan for Analysis of Tank 5F and 6F $\mathrm{F}^{\mathrm{i}}$. One piece of cooling coil sample was obtained from a section of a vertical cooling coil located above the 45-inch elevation from the tank floor and designated as sample 5-R1-A45 and the other sample also from a vertical section of a cooling coil located below the 45-inch elevation from the tank floor of Tank 5F and designated as sample 5-R1-B45. The measurements were requested to estimate the radionuclides trapped in the corrosion layer on the exterior of the cooling coils in the waste tank. Process history indicates that there are no radionuclides in the interior surface area of the cooling coils. Only chromate solutions were pumped through the interior of the cooling coils.

\subsection{Experimental Procedure}

Figure 1 shows a picture of the two Tank $5 \mathrm{~F}$ cooling coil samples taken inside the shielded cell at SRNL. A Milwaukee deep cut portable electric band saw and band saw table (model 6232-6N saw and saw table model 48-08-0260) were installed in the shielded cell and were used to cut each of the Tank 5F cooling coil samples (TK 5-R1-B45 and TK 5-R1-A45) into 3-inch long segments. Prior to use in the cell, the band saw unit was modified to enhance remote operation capabilities and control from outside the shielded cell. This involved modifications of the on and off switch buttons and rewiring for remote control.

Since the external radius of the cooling coil samples could not be measured directly with an acceptable degree of accuracy inside the cell, the radius of the two samples were based on the external diameter of a 2-inch internal diameter pipe (schedule 40) with similar properties and dimensions as the one used in the original construction of the Tank $5 \mathrm{~F}$ cooling coils. However, the length of the cooling coil segments were based on direct measurement obtained from the cut Tank 5F sample pieces. The external radius values used for surface area calculations, which were derived from the 2-inch internal diameter pipe (schedule 40) blank sample as described above averaged $1.1875 \pm 0.0594$ inches. The average surface area for these Tank 5F samples, 5-R1-A45 and 5-R1-B45 were 0.326 and 0.325 square feet, respectively. The external surface for the reference or blank 2-inch internal diameter pipe (schedule 40) was 0.155 square feet.

In a typical leaching sequence, two segments of 3-inch long cooling coil samples were leached in a glass leaching vessel as shown in Figure 2, insert A. The leaching procedure was performed in an acid medium consisting of aqua-regia (concentrated $\mathrm{HCL}$ [300 $\mathrm{mL}]$ and concentrated $\mathrm{HNO}_{3}$ [75 mL]). Thus, approximately 6-inch portions of the coil were leached into each vessel. The leachate from the coil segments was considered as one of three such samples for each of the two Tank 5F cooling coils (leaching was performed in triplicate for each Tank 5F cooling coil). Each

3 -inch segment was leached in the acid for a total of 30 minutes. Because the height of the leaching solution was only about $3 / 4$ of the height of each 3 -inch segment in the leaching vessel, it was necessary to invert each sample segment after 15 minutes to ensure that the whole sample piece was completely leached, in order words, each half of the 3 -inch segment received a total of 15 minutes contact time with the leaching solution. In all, about 18 inches of the cooling coil pipes from each sample (5-R1-A45 and 5-R1-B45) were leached. The resulting leachate was transferred into a 500-mL capacity volumetric flask and adjusted to the mark with de-ionized and distilled water before transferring the solution back into the same leaching vessel for analytical 
sampling and storage. The photograph shown in Figure 2, insert B, shows a post leaching sample taken out of the leaching vessel.

Secondary leaching was also performed on each pair of the 3-inch cooling coil samples using a separate leaching vessel and the process repeated as in the initial leaching described above. Secondary leaching of each sample was necessary to ensure that the initial leaching was adequate to remove the majority of each of the customer specified radionuclides. Thus, one would expect that the concentration of radionuclides in the corresponding secondary leachate was lower than in the initial leachate. The analytical results were used to confirm this expectation.

\subsection{Blank Evaluations}

To verify the absence of sample contamination during processing in the shielded cell of these cooling coil pieces, a 2-inch internal diameter pipe (schedule 40) with the similar properties and dimensions as the one used in the construction of the Tank $5 \mathrm{~F}$ cooling coils was used as the analytical blank material for comparison. This pipe was cut and leached in the cell in a similar fashion as described above for the Tank 5F cooling coils. The leachate from this reference pipe was analyzed for the same radionuclide as those of the Tank $5 \mathrm{~F}$ cooling coils. The analytical results for the customer specified radionuclides from the schedule 40 blank leachate were compared to the analytical results from the Tank $5 \mathrm{~F}$ cooling coils leachate.

\subsection{Results}

In the Tank $5 \mathrm{~F}$ cooling coil leachate characterization results presented below, values preceded by "<" (less than sign) indicate values were below minimum detection limits MDLs, and values proceeded by " $\leq$ " (less than or equal to sign) indicate that for replicates, at least one of the analysis values was above the instrument or method detection limit (MDL). Thus, where replicate analyses were both above and below the MDL, the average of all replicates is given a " $\leq$ "sign, which precedes the average value. The standard deviation values were calculated only for values that were above the minimum detection limits. The minimum detectable activity (MDA) is defined as the value above which instrument signal can be considered real and the upper limit (UL) is defined as activity observed but not certain if the result is not biased high due to spectral interference.

The one sigma percent uncertainty for each major radionuclide, as reported in the tables, is based on the pooled estimate derived from the individual uncertainties for each replicate measurement for that radionuclide $\left[\left[\operatorname{SQRT}\left(\left(\operatorname{SUMSQ}\left(\mathrm{x}_{\mathrm{i}}\right) / \mathrm{n}\right)\right)\right]\right.$, where $\mathrm{n}$ is the number of replicates and $\mathrm{x}_{\mathrm{i}}$ is the individual uncertainty associated with each radionuclide for each run]. Here it is assumed that the radio-analytical processes, be it by counting or other non radiometric technique, is of the same precision for each individual measurement.

Individual radionuclide activities (Appendices B-1 and B-2) in the second leaching of each cooling coil piece are about an order of magnitude lower than the corresponding initial leachate radionuclide activity for each coil sample. This confirms that most radionuclides of interest were leached out in the initial phase of leaching each coil. Summaries of the data for secondary leaching of both cooling coil samples, used for determination of leaching effectiveness, are presented in Appendix B-1 and B-2.

The SRNL AD tracking numbers for all Tank 5F cooling coil leachate characterizations are summarized in Appendix A-1 and A-2, while the individual cooling coil piece length and weight changes after initial leaching are summarized in Appendix A-3. 
Radionuclide analysis results from both cooling coils (upper and lower), as summarized in Tables 1 and 2 below, show that the predominant radionuclide contributing to the activities in the upper and lower segments of the coils, respectively, are strontium-90 and cesium-137, averaging, respectively, 1.34E-02 and $8.93 \mathrm{E}-03 \mathrm{Ci} / \mathrm{ft}^{2}$ for $\mathrm{Sr}-90$ and $7.27 \mathrm{E}-04$ and $8.10 \mathrm{E}-04 \mathrm{Ci} / \mathrm{ft}^{2}$ for $\mathrm{Cs}-137$. Other significant activity contributing radionuclides on both cooling coils included americium241 and europium-154/155. With the exception of the analysis result for Pu-241 in the A45 cooling coils samples, the target detection limits for the other radionuclides were met in both cooling coil samples. The detection limits for Pu-241 analyses result in coil sample A45 were not met consistently because of possible background changes during liquid scintillation counting, which may have raised the values for $\mathrm{Pu}-241$ even in the reference sample.

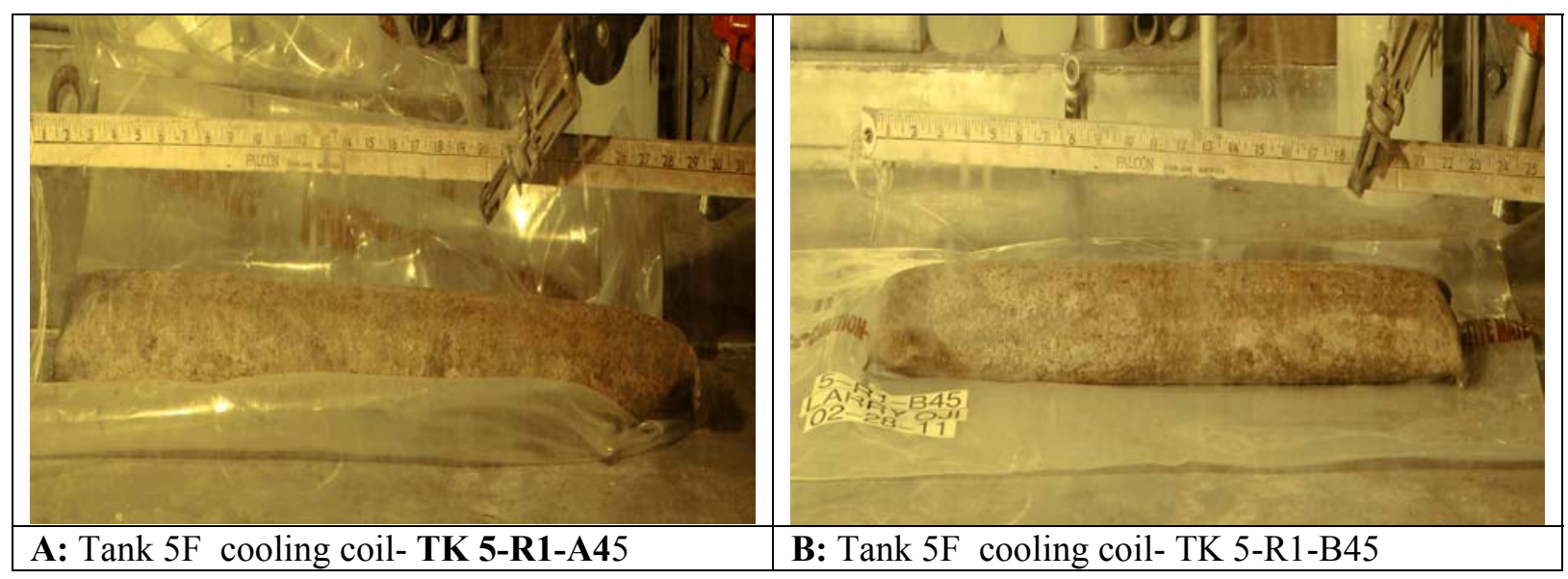

Figure 1. Inserts $A$ and $B$ show pictures of two vertical cooling coils taken from Riser 1 in Tank 5F. Picture was taken inside SRNL shielded cell.

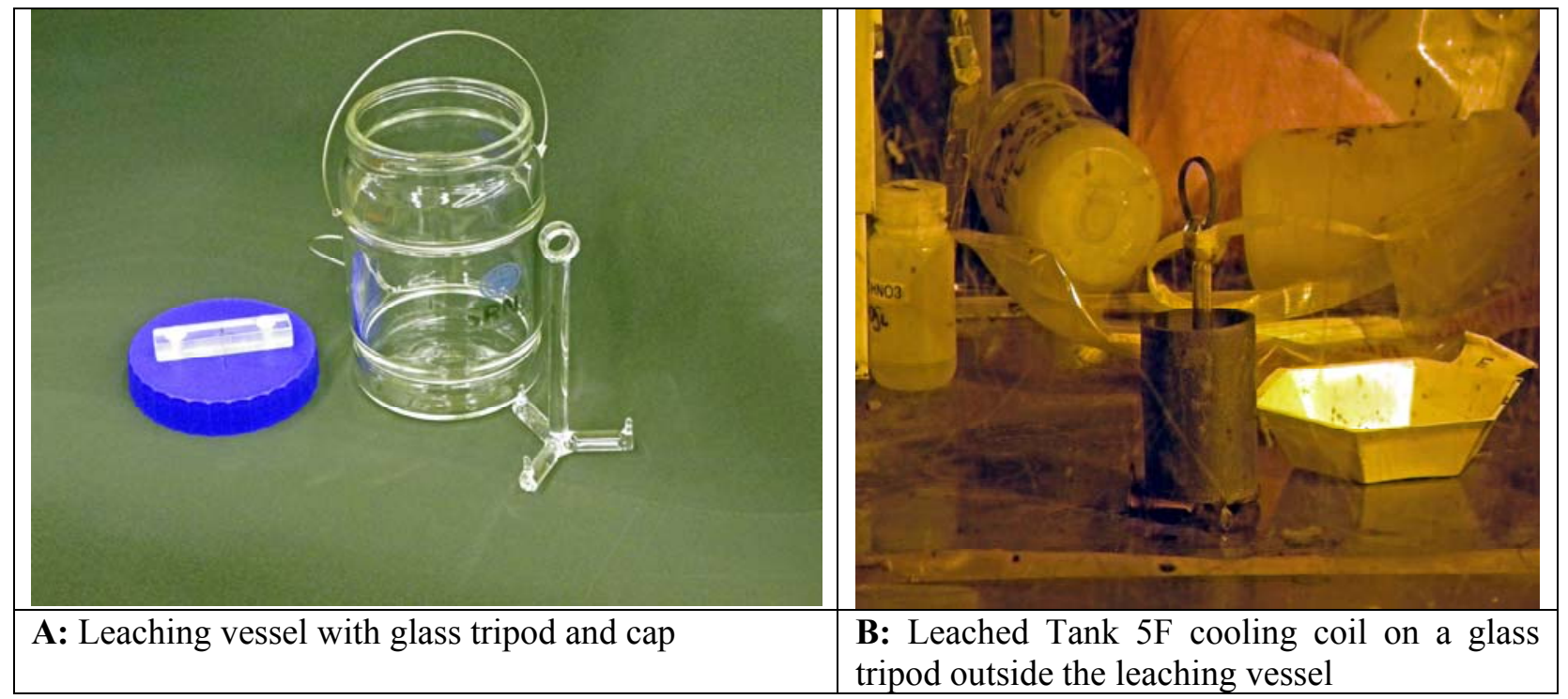

Figure 2 Leaching vessel and a typical leached Tank 5F cooling coil (insert B). 
Table 1. Radiological Analytes for Tank 5F A45 Cooling Coil (First leach): Coil located above the 45-inch elevation of Tank 5F.

\begin{tabular}{|c|c|c|c|c|c|c|c|c|}
\hline Analytes & $\begin{array}{c}\text { Reference } \\
\text { Blank } \\
\text { Ci/ft } \\
\end{array}$ & $\begin{array}{c}\text { Run } 1 \\
\mathrm{Ci} / \mathbf{f t}^{2}\end{array}$ & $\begin{array}{c}\text { Run } 2 \\
\mathrm{Ci} / \mathbf{f t}^{2}\end{array}$ & $\begin{array}{c}\text { Run } 3 \\
\mathrm{Ci} / \mathbf{f t}^{2}\end{array}$ & $\begin{array}{c}\text { Average } \\
\mathbf{C i} / \mathbf{f t}^{2}\end{array}$ & Stdev. & $\begin{array}{c}\text { One Sigma } \\
\text { \%Uncertainty } \\
\text { Runs 1-3 } \\
\end{array}$ & $\begin{array}{c}\text { Target } \\
\text { Detection } \\
\mathbf{C i}^{\prime} / \mathbf{f t}^{2^{*}} \\
\end{array}$ \\
\hline Co-60 & $<1.00 \mathrm{E}-08$ & $3.24 \mathrm{E}-06$ & $3.64 \mathrm{E}-06$ & $3.47 \mathrm{E}-06$ & $3.45 \mathrm{E}-06$ & $2.02 E-07$ & 5.0 & $8.3 \mathrm{E}-06$ \\
\hline Sr-90 & $<3.44 \mathrm{E}-05$ & $1.24 \mathrm{E}-02$ & $1.46 \mathrm{E}-02$ & $1.38 \mathrm{E}-02$ & $1.34 \mathrm{E}-02$ & $1.12 E-03$ & 6.6 & 5.9E-02 \\
\hline Cs-137 & $<1.30 \mathrm{E}-07$ & $6.86 \mathrm{E}-04$ & $7.75 \mathrm{E}-04$ & $7.22 \mathrm{E}-04$ & $7.27 E-04$ & $4.46 E-05$ & 5.0 & $4.2 \mathrm{E}-03$ \\
\hline U-233 & $<2.60 \mathrm{E}-07$ & $<8.41 \mathrm{E}-09$ & $<9.28 \mathrm{E}-09$ & $<8.19 \mathrm{E}-09$ & $<8.63 E-09$ & & $\mathrm{DL}$ & $1.1 \mathrm{E}-07$ \\
\hline U-234 & $<1.67 \mathrm{E}-07$ & $<5.43 \mathrm{E}-09$ & $<5.97 \mathrm{E}-09$ & $<5.28 \mathrm{E}-09$ & $<5.56 \mathrm{E}-09$ & & DL & $7.8 \mathrm{E}-08$ \\
\hline U-235 & $<5.81 \mathrm{E}-11$ & $1.29 \mathrm{E}-10$ & $1.41 \mathrm{E}-10$ & $1.66 \mathrm{E}-10$ & $1.45 \mathrm{E}-10$ & $1.90 E-11$ & 20 & $2.7 \mathrm{E}-09$ \\
\hline U-236 & $<1.74 \mathrm{E}-09$ & $1.66 \mathrm{E}-10$ & $1.74 \mathrm{E}-10$ & $2.12 \mathrm{E}-10$ & 1.84E-10 & $2.47 E-11$ & 20 & $4.6 \mathrm{E}-07$ \\
\hline $\mathrm{U}-238$ & $<1.08 \mathrm{E}-11$ & $3.20 \mathrm{E}-09$ & $3.46 \mathrm{E}-09$ & $4.14 \mathrm{E}-09$ & 3.60E-09 & $4.85 E-10$ & 20 & $7.8 \mathrm{E}-08$ \\
\hline $\mathrm{Np}-237$ & $<5.68 \mathrm{E}-09$ & $1.09 \mathrm{E}-08$ & $1.15 \mathrm{E}-08$ & $1.09 \mathrm{E}-08$ & $1.11 \mathrm{E}-08$ & $3.61 E-10$ & & $1.1 \mathrm{E}-07$ \\
\hline $\mathrm{Pu}-238$ & $<1.73 \mathrm{E}-07$ & $8.72 \mathrm{E}-07$ & $1.13 \mathrm{E}-06$ & $9.42 \mathrm{E}-07$ & 9.80E-07 & $1.31 E-07$ & 11.0 & $6.5 \mathrm{E}-05$ \\
\hline $\mathrm{Pu}-239$ & $<2.50 \mathrm{E}-08$ & $2.21 \mathrm{E}-06$ & $1.96 \mathrm{E}-06$ & $2.18 \mathrm{E}-06$ & 2.12E-06 & $1.38 E-07$ & 20 & $1.5 \mathrm{E}-05$ \\
\hline $\mathrm{Pu}-240$ & $<9.16 \mathrm{E}-08$ & $5.67 \mathrm{E}-07$ & $5.10 \mathrm{E}-07$ & $5.65 \mathrm{E}-07$ & 5.47E-07 & $3.27 E-08$ & 20 & $3.3 \mathrm{E}-06$ \\
\hline $\mathrm{Pu}-241$ & $<2.01 \mathrm{E}-05$ & $<9.54 \mathrm{E}-06$ & $<4.30 \mathrm{E}-05$ & $<3.81 \mathrm{E}-05$ & $<3.02 E-05$ & & Upper limit & $1.5 \mathrm{E}-05$ \\
\hline $\mathrm{Pu}-242$ & $<1.59 \mathrm{E}-09$ & $1.38 \mathrm{E}-10$ & $1.30 \mathrm{E}-10$ & $1.32 \mathrm{E}-10$ & 1.33E-10 & $4.18 E-12$ & 20 & $4.6 \mathrm{E}-07$ \\
\hline $\mathrm{Pu}-244$ & $<7.39 \mathrm{E}-12$ & $<4.27 \mathrm{E}-13$ & $<4.03 \mathrm{E}-13$ & $<4.55 \mathrm{E}-13$ & $<4.28 \mathrm{E}-13$ & & $\mathrm{DL}$ & $2.3 \mathrm{E}-09$ \\
\hline Am-241 & $<5.51 \mathrm{E}-08$ & $1.08 \mathrm{E}-05$ & $1.24 \mathrm{E}-05$ & $1.13 \mathrm{E}-05$ & 1.15E-05 & $8.32 E-07$ & 5.0 & $2.7 \mathrm{E}-04$ \\
\hline Gross alpha & $<2.98 \mathrm{E}-05$ & $<7.48 \mathrm{E}-05$ & $<7.12 \mathrm{E}-05$ & $<1.91 \mathrm{E}-04$ & $<1.12 \mathrm{E}-04$ & & Upper limit & NA \\
\hline $\begin{array}{c}\text { Non-volatile } \\
\text { beta }\end{array}$ & $<6.79 \mathrm{E}-05$ & $2.92 \mathrm{E}-02$ & $3.37 \mathrm{E}-02$ & $3.46 \mathrm{E}-02$ & $3.25 \mathrm{E}-02$ & $2.89 E-03$ & 10.0 & NA \\
\hline Eu-154 & $<1.30 \mathrm{E}-08$ & $5.29 \mathrm{E}-06$ & $6.20 \mathrm{E}-06$ & $5.98 \mathrm{E}-06$ & 5.82E-06 & $4.75 E-07$ & 5.0 & NA \\
\hline Eu-155 & $<2.59 \mathrm{E}-08$ & $7.90 \mathrm{E}-07$ & $1.19 \mathrm{E}-06$ & $8.42 \mathrm{E}-07$ & 9.41E-07 & $2.18 E-07$ & 11.0 & NA \\
\hline Sb-126 & $<9.49 \mathrm{E}-09$ & $<1.47 \mathrm{E}-08$ & $<4.95 \mathrm{E}-08$ & $<3.06 \mathrm{E}-08$ & $<3.16 \mathrm{E}-08$ & & MDA & NA \\
\hline $\mathrm{Cm}-242$ & $<9.15 \mathrm{E}-10$ & $2.33 \mathrm{E}-08$ & $1.97 \mathrm{E}-08$ & $1.96 \mathrm{E}-08$ & 2.09E-08 & $2.11 E-09$ & 22.1 & NA \\
\hline $\mathrm{Cm}-244$ & $<3.72 \mathrm{E}-08$ & $9.96 \mathrm{E}-07$ & $9.32 \mathrm{E}-07$ & $8.42 \mathrm{E}-07$ & 9.23E-07 & $7.72 E-08$ & 15.2 & $\mathrm{NA}$ \\
\hline
\end{tabular}

* Target detection information was provided by the customer. 
Table 2 Radiological Analytes for Cooling Coil Tank 5F B45 (First leach): Coil located below the 45-inch elevation of Tank 5F.

\begin{tabular}{|c|c|c|c|c|c|c|c|c|}
\hline Analytes & $\begin{array}{c}\text { Reference } \\
\text { Blank } \\
\mathbf{C i} / \mathbf{f t}^{2}\end{array}$ & $\underset{\mathbf{C i} / \mathbf{f t ^ { 2 }}}{\operatorname{Run} 1}$ & $\underset{C i / f t^{2}}{\operatorname{Run} 2}$ & $\begin{array}{r}\operatorname{Run} 3 \\
\mathbf{C i} / \mathbf{f t}^{2}\end{array}$ & $\begin{array}{c}\text { Average } \\
\mathbf{C i} / \mathbf{f t}^{2}\end{array}$ & Stdev. & $\begin{array}{c}\text { One Sigma } \\
\text { \%Uncertainty } \\
\text { Runs 1-3 }\end{array}$ & $\begin{array}{c}\text { Target } \\
\text { Detection } \\
\mathbf{C i} / \mathbf{f t}^{2 *}\end{array}$ \\
\hline Co-60 & $1.64 \mathrm{E}-08$ & $5.13 \mathrm{E}-06$ & $7.88 \mathrm{E}-06$ & $6.12 \mathrm{E}-06$ & $6.37 \mathrm{E}-06$ & $1.39 \mathrm{E}-06$ & 5.0 & $8.3 \mathrm{E}-06$ \\
\hline Sr-90 & $5.07 \mathrm{E}-05$ & 8.04E-03 & $9.67 \mathrm{E}-03$ & $9.09 \mathrm{E}-03$ & 8.93E-03 & $8.25 \mathrm{E}-04$ & 7.0 & 5.9E-02 \\
\hline Cs-137 & $2.37 \mathrm{E}-06$ & $7.38 \mathrm{E}-04$ & $8.57 \mathrm{E}-04$ & $8.36 \mathrm{E}-04$ & 8.10E-04 & $6.36 E-05$ & 5.0 & $4.2 \mathrm{E}-03$ \\
\hline U-233 & $<1.05 \mathrm{E}-08$ & $<1.69 \mathrm{E}-09$ & $<1.44 \mathrm{E}-09$ & $<1.51 \mathrm{E}-09$ & $<1.55 \mathrm{E}-09$ & & $\mathrm{DL}$ & $1.1 \mathrm{E}-07$ \\
\hline U-234 & $<6.77 \mathrm{E}-09$ & $1.70 \mathrm{E}-09$ & $2.71 \mathrm{E}-09$ & $2.59 \mathrm{E}-09$ & $2.34 \mathrm{E}-09$ & $5.50 E-10$ & 20.0 & $7.8 \mathrm{E}-08$ \\
\hline U-235 & $<2.35 \mathrm{E}-12$ & $9.11 \mathrm{E}-11$ & $1.45 \mathrm{E}-10$ & $1.42 \mathrm{E}-10$ & $1.26 \mathrm{E}-10$ & $3.02 E-11$ & 20.0 & $2.7 \mathrm{E}-09$ \\
\hline U-236 & $<7.03 \mathrm{E}-11$ & $1.03 \mathrm{E}-10$ & $1.61 \mathrm{E}-10$ & $1.56 \mathrm{E}-10$ & $1.40 \mathrm{E}-10$ & $3.25 E-11$ & 20.0 & 4.6E-07 \\
\hline U-238 & $<1.08 \mathrm{E}-11$ & $1.96 \mathrm{E}-09$ & $3.21 \mathrm{E}-09$ & $3.16 \mathrm{E}-09$ & $2.78 \mathrm{E}-09$ & $7.03 E-10$ & 20.0 & $7.8 \mathrm{E}-08$ \\
\hline $\mathrm{Np}-237$ & $<5.68 \mathrm{E}-09$ & $1.42 \mathrm{E}-08$ & $1.35 \mathrm{E}-08$ & $1.30 \mathrm{E}-08$ & $1.36 \mathrm{E}-08$ & $6.03 E-10$ & 20.0 & $1.1 \mathrm{E}-07$ \\
\hline Pu-238 & $2.09 \mathrm{E}-08$ & $1.65 \mathrm{E}-06$ & $2.16 \mathrm{E}-06$ & $1.50 \mathrm{E}-06$ & $1.77 \mathrm{E}-06$ & $3.46 E-07$ & 5.1 & $6.5 \mathrm{E}-05$ \\
\hline $\mathrm{Pu}-239$ & $1.99 \mathrm{E}-08$ & $4.48 \mathrm{E}-06$ & $6.58 \mathrm{E}-06$ & $4.42 \mathrm{E}-06$ & $5.16 \mathrm{E}-06$ & $1.23 E-06$ & 20.0 & $1.5 \mathrm{E}-05$ \\
\hline $\mathrm{Pu}-240$ & $1.01 \mathrm{E}-08$ & $1.08 \mathrm{E}-06$ & $1.56 \mathrm{E}-06$ & $1.05 \mathrm{E}-06$ & $1.23 E-06$ & $2.91 E-07$ & 20.0 & $3.3 \mathrm{E}-06$ \\
\hline $\mathrm{Pu}-241$ & $<4.01 \mathrm{E}-06$ & $<4.91 \mathrm{E}-06$ & $<1.06 \mathrm{E}-05$ & $<1.65 \mathrm{E}-05$ & $<1.07 \mathrm{E}-05$ & & Upper limit & $1.5 \mathrm{E}-05$ \\
\hline $\mathrm{Pu}-242$ & $<1.46 \mathrm{E}-10$ & $2.22 \mathrm{E}-10$ & $3.04 \mathrm{E}-10$ & $2.12 \mathrm{E}-10$ & $2.46 \mathrm{E}-10$ & $5.02 E-11$ & 20.0 & $4.6 \mathrm{E}-07$ \\
\hline $\mathrm{Pu}-244$ & $<6.81 \mathrm{E}-13$ & $<3.90 \mathrm{E}-13$ & $<4.95 \mathrm{E}-13$ & $<3.95 \mathrm{E}-13$ & $<4.27 \mathrm{E}-13$ & & DL & $2.3 \mathrm{E}-09$ \\
\hline Am-241 & $1.08 \mathrm{E}-07$ & $2.79 \mathrm{E}-05$ & $4.12 \mathrm{E}-05$ & $2.92 \mathrm{E}-05$ & $3.28 \mathrm{E}-05$ & $7.38 \mathrm{E}-06$ & 5.0 & $2.7 \mathrm{E}-04$ \\
\hline $\begin{array}{l}\text { Gross } \\
\text { alpha }\end{array}$ & $<3.43 \mathrm{E}-05$ & $<5.33 \mathrm{E}-05$ & $<8.29 \mathrm{E}-05$ & $<6.91 \mathrm{E}-05$ & $<6.85 \mathrm{E}-05$ & & MDA & NA \\
\hline Gross beta & $1.00 \mathrm{E}-04$ & $1.69 \mathrm{E}-02$ & $2.40 \mathrm{E}-02$ & $2.15 \mathrm{E}-02$ & $2.08 \mathrm{E}-02$ & $3.64 E-03$ & 10.0 & NA \\
\hline Sb-126 & $<1.12 \mathrm{E}-09$ & $<9.36 \mathrm{E}-08$ & $<1.17 \mathrm{E}-07$ & $8.76 \mathrm{E}-08$ & $\leq 9.95 \mathrm{E}-08$ & & MDA/9.51 & NA \\
\hline Eu-154 & $4.74 \mathrm{E}-08$ & $1.16 \mathrm{E}-05$ & $1.85 \mathrm{E}-05$ & $1.24 \mathrm{E}-05$ & $1.42 \mathrm{E}-05$ & $3.80 \mathrm{E}-06$ & 5.0 & NA \\
\hline Eu-155 & $7.54 \mathrm{E}-09$ & $1.87 \mathrm{E}-06$ & $2.62 \mathrm{E}-06$ & $2.25 \mathrm{E}-06$ & 2.25E-06 & $3.73 \mathrm{E}-07$ & 10.3 & NA \\
\hline $\mathrm{Cm}-242$ & $<2.08 \mathrm{E}-08$ & $6.82 \mathrm{E}-08$ & $8.77 \mathrm{E}-08$ & $3.35 \mathrm{E}-08$ & $6.31 \mathrm{E}-08$ & $2.75 E-08$ & 54.0 & NA \\
\hline Cm-244 & $<5.67 \mathrm{E}-08$ & $2.24 \mathrm{E}-06$ & $3.54 \mathrm{E}-06$ & $2.50 \mathrm{E}-06$ & $2.76 \mathrm{E}-06$ & $6.91 E-07$ & 6.6 & NA \\
\hline
\end{tabular}

* Target detection information was provided by the customer

\subsection{Conclusions}

Analyses results from both cooling coils as summarized above in Tables 1 and 2, show that the predominant radionuclides contributing to most of the activity in both coils are strontium-90 and cesium-137. The activities for strontium-90 and cesium-137 in the Tank 5F vertical cooling coil located above the 45-inches elevation of the tank and designated as sample 5-R1-A45 averaged, respectively, $1.34 \mathrm{E}-02 \pm 1.12 \mathrm{E}-03$ and $7.27 \mathrm{E}-04 \pm 4.46 \mathrm{E}-05 \mathrm{Ci} / \mathrm{ft}^{2}$, while the activities for the tank vertical cooling coil located below the 45-inches elevation of the tank and designated as sample 5-R1-B45 averaged 8.93E-03 $\pm 8.25 E-04$ for Sr-90 and $8.10 \mathrm{E}-04 \pm 6.36 E-05 \mathrm{Ci} / \mathrm{ft}^{2}$, for Cs-137. Other significant activity contributing radionuclides include americium-241 and europium-154/155.

With the exception of Pu-241-analyses result for Tank 5F cooling coil sample 5-R1-A45, all requested radionuclide detection limits for the leaching and characterization of both cooling coil samples were met. The detection limits for Pu-241 analyses result in coil sample A45 were not met consistently because of possible background changes during liquid scintillation counting which may have raised the values for Pu-241 even in the reference blank sample.

$\mathrm{Pu}-241$ analyses result for Tank 5F cooling coil sample 5-R1-A45 averaged about the same order of magnitude $\left(<3.02 \mathrm{E}-05 \mathrm{Ci} / \mathrm{ft}^{2}\right)$ as the requested target detection limit $\left(1.5 \mathrm{E}-05 \mathrm{Ci} / \mathrm{ft}^{2}\right)$. 
SRNL-STI-2011-00372, Revision 0

\subsection{References}

${ }^{\mathrm{i}}$ Lawrence N. Oji and David Diprete, "Task Technical and Quality Assurance Plan for Analysis of the Tank 5F and Tank 6F Final Characterization Samples-2011" (U), SRNL-RP-2010-01695, Rev. 1, December 2, 2010 


\section{Appendix A-1}

Analytical Tracking Numbers for Cooling Coil Sample 5-R1-A45

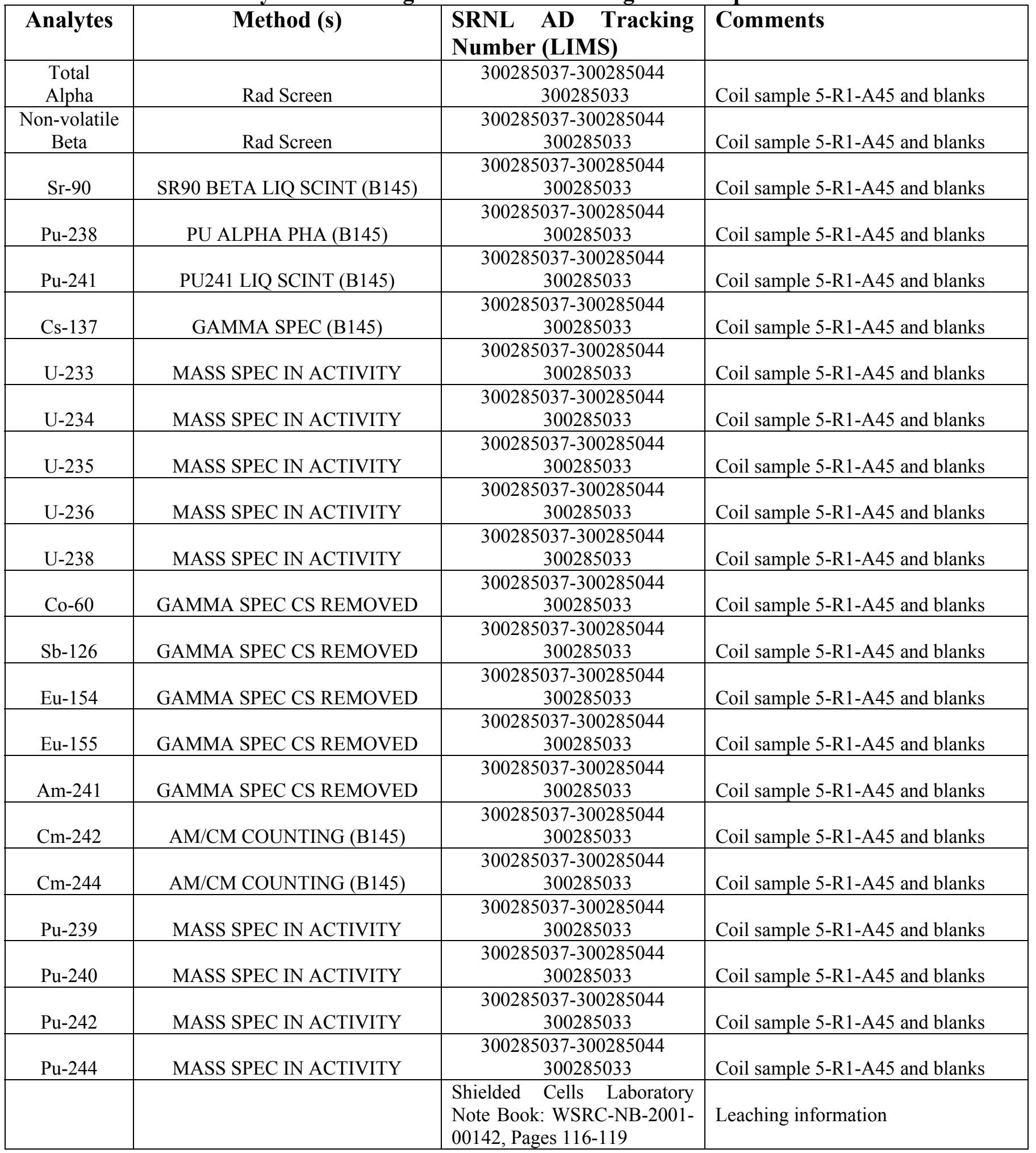




\section{Appendix A-2}

Analytical Tracking Numbers for Cooling Coil Sample 5-R1-B45

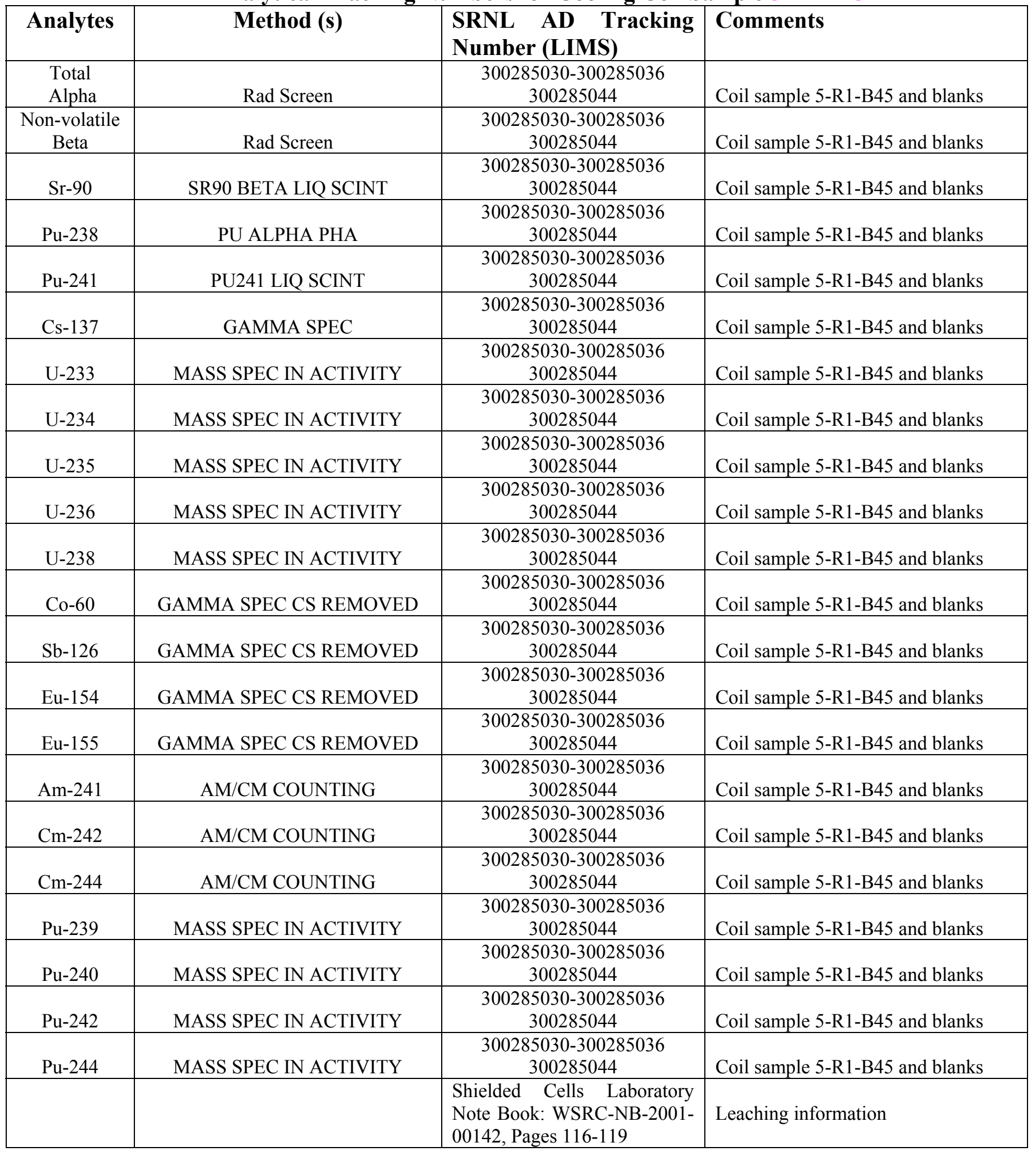




\section{Appendix A-3}

Individual Weight, Length and Weight Changes after Initial Leaching of Coil Piece Segments

\begin{tabular}{|c|c|c|c|c|c|c|}
\hline Cooling Coil ID & $\begin{array}{l}\text { Cooling coil } \\
\text { piece ID }\end{array}$ & $\begin{array}{l}\text { Cooling Coil } \\
\text { piece length, } \\
\text { inches }\end{array}$ & $\begin{array}{l}\text { Wt. of cooling } \\
\text { piece, } \\
\text { (initial leaching), } \\
\text { g }\end{array}$ & $\begin{array}{l}\text { Cooling Coil } \\
\text { piece: post- } \\
\text { leaching wt. } \\
\text { (initial leaching), g }\end{array}$ & $\begin{array}{l}\text { Wt. of cooling } \\
\text { coil leached } \\
\text { (initial leaching), g }\end{array}$ & $\begin{array}{l}\text { \% leached. } \\
\text { (initial leaching) }\end{array}$ \\
\hline \multirow[t]{2}{*}{ 5-R1-A45 } & A45-1-L1 & 3.13 & 414.18 & 390.58 & 23.60 & 5.7 \\
\hline & A45-1-L2 & 3.20 & 415.91 & 383.28 & 32.63 & 7.8 \\
\hline \multirow[t]{2}{*}{ 5-R1-A45 } & A45-2-L1 & 3.06 & 403.74 & 395.77 & 7.97 & 2.0 \\
\hline & A45-2-L2 & 3.00 & 399.31 & 350.64 & 48.67 & 12.2 \\
\hline \multirow[t]{2}{*}{ 5-R1-A45 } & A45-3-L1 & 3.25 & 429.54 & 423.31 & 6.23 & 1.5 \\
\hline & A45-3-L2 & 3.25 & 429.06 & 377.15 & 51.91 & 12.1 \\
\hline \multirow[t]{2}{*}{ Reference coil-A } & Reference A & 3.00 & 429.05 & 396.33 & 32.72 & 7.6 \\
\hline & & & & & & \\
\hline \multirow[t]{2}{*}{ 5-R1-B45 } & B45-1-L1 & 3.65 & 508.68 & 477.71 & 30.97 & 6.1 \\
\hline & B45-1-L2 & 2.30 & 290.81 & 264.37 & 26.44 & 9.1 \\
\hline \multirow[t]{2}{*}{ 5-R1-B45 } & B45-2-L1 & 3.20 & 438.62 & 399.97 & 38.65 & 8.8 \\
\hline & B45-2-L2 & 3.10 & 430.11 & 400.71 & 29.40 & 6.8 \\
\hline \multirow[t]{2}{*}{ 5-R1-B45 } & B45-3-L1 & 3.25 & 458.45 & 446.35 & 12.10 & 2.6 \\
\hline & B45-3-L2 & 3.35 & 476.28 & 433.78 & 42.50 & 8.9 \\
\hline Reference coil-B & Reference B & 3.00 & 419.22 & 399.88 & 19.34 & 4.6 \\
\hline
\end{tabular}




\section{Appendix B-1}

Radiological Analytes for Tank 5F A45 Cooling Coil (Second leach): Coil located above the 45inches elevation of Tank 5F.

\begin{tabular}{|c|c|c|c|c|c|c|c|c|}
\hline Analytes & $\begin{array}{c}\text { Reference } \\
\text { Blank } \\
\mathbf{C i} / \mathbf{f t}^{2}\end{array}$ & $\begin{array}{c}\text { Run 1 } \\
\mathbf{C i} / \mathbf{f} \mathbf{t}^{2}\end{array}$ & $\begin{array}{l}\text { Run } 2 \\
\mathbf{C i} / \mathbf{f t}^{2}\end{array}$ & $\begin{array}{r}\text { Run } 3 \\
\mathbf{C i} / \mathbf{f t}^{2}\end{array}$ & $\begin{array}{c}\text { Average } \\
\mathbf{C i} / \mathbf{f t}^{2}\end{array}$ & Stdev. & $\begin{array}{l}\text { One Sigma } \\
\text { \%Uncertainty } \\
\text { Runs 1-3 }\end{array}$ & $\begin{array}{c}\text { Target } \\
\text { Detection } \\
\mathbf{C i} / \mathbf{f t}^{2}\end{array}$ \\
\hline Co-60 & $<1.00 \mathrm{E}-08$ & $2.93 \mathrm{E}-07$ & $4.46 \mathrm{E}-07$ & $5.19 \mathrm{E}-07$ & $4.19 \mathrm{E}-07$ & $1.15 E-07$ & 5.0 & $8.3 \mathrm{E}-06$ \\
\hline Sr-90 & $<3.44 \mathrm{E}-05$ & $1.02 \mathrm{E}-03$ & $1.11 \mathrm{E}-03$ & $1.27 \mathrm{E}-03$ & $1.13 \mathrm{E}-03$ & $1.28 \mathrm{E}-04$ & 6.9 & $5.9 \mathrm{E}-02$ \\
\hline Cs-137 & $<1.30 \mathrm{E}-07$ & $9.27 \mathrm{E}-05$ & $1.23 \mathrm{E}-04$ & $2.80 \mathrm{E}-04$ & $1.65 \mathrm{E}-04$ & $1.01 E-04$ & 5.0 & $4.2 \mathrm{E}-03$ \\
\hline $\mathrm{U}-233$ & $<2.60 \mathrm{E}-07$ & $<1.10 \mathrm{E}-08$ & $<1.10 \mathrm{E}-08$ & $<9.11 \mathrm{E}-09$ & $<1.03 \mathrm{E}-08$ & & $\mathrm{Dl}$ & $1.1 \mathrm{E}-07$ \\
\hline U-234 & $<1.67 \mathrm{E}-07$ & $<7.06 \mathrm{E}-09$ & $<7.07 \mathrm{E}-09$ & $<<5.86 \mathrm{E}-09$ & $\begin{array}{c}<6.66 \mathrm{E}-09 \\
\end{array}$ & & $\mathrm{DL}$ & $7.8 \mathrm{E}-08$ \\
\hline U-235 & $<5.81 \mathrm{E}-11$ & $1.74 \mathrm{E}-11$ & $2.21 \mathrm{E}-11$ & $2.28 \mathrm{E}-11$ & $2.08 \mathrm{E}-11$ & $2.97 E-12$ & 20.0 & $2.7 \mathrm{E}-09$ \\
\hline U-236 & $<1.74 \mathrm{E}-09$ & $<7.35 \mathrm{E}-11$ & $<7.36 \mathrm{E}-11$ & $<6.11 \mathrm{E}-11$ & $<6.94 \mathrm{E}-11$ & & $\mathrm{DL}$ & $4.6 \mathrm{E}-07$ \\
\hline U-238 & $<1.08 \mathrm{E}-11$ & $4.25 \mathrm{E}-10$ & $5.53 \mathrm{E}-10$ & $5.82 \mathrm{E}-10$ & $5.20 \mathrm{E}-10$ & $8.31 E-11$ & 20.0 & $7.8 \mathrm{E}-08$ \\
\hline $\mathrm{Np}-237$ & $<5.68 \mathrm{E}-09$ & $<2.69 \mathrm{E}-09$ & $<2.81 \mathrm{E}-09$ & $<2.61 \mathrm{E}-09$ & $<2.70 \mathrm{E}-09$ & & MDA & $1.1 \mathrm{E}-07$ \\
\hline $\mathrm{Pu}-238$ & $<1.73 \mathrm{E}-07$ & $1.35 \mathrm{E}-07$ & $1.97 \mathrm{E}-07$ & $2.51 \mathrm{E}-07$ & $1.94 \mathrm{E}-07$ & $5.77 \mathrm{E}-08$ & 20.0 & $6.5 \mathrm{E}-05$ \\
\hline $\mathrm{Pu}-239$ & $<2.50 \mathrm{E}-08$ & $2.49 \mathrm{E}-07$ & $3.89 \mathrm{E}-07$ & $2.54 \mathrm{E}-07$ & $2.97 \mathrm{E}-07$ & $7.94 E-08$ & 20.0 & $1.5 \mathrm{E}-05$ \\
\hline $\mathrm{Pu}-240$ & $<9.16 \mathrm{E}-08$ & $6.81 \mathrm{E}-08$ & $1.07 \mathrm{E}-07$ & $6.77 \mathrm{E}-08$ & $8.08 \mathrm{E}-08$ & $2.23 E-08$ & 20.0 & $3.3 \mathrm{E}-06$ \\
\hline $\mathrm{Pu}-241$ & $<2.01 \mathrm{E}-05$ & $<7.14 \mathrm{E}-07$ & $<9.32 \mathrm{E}-07$ & $<9.22 \mathrm{E}-06$ & $<3.62 \mathrm{E}-06$ & & Upper limit & $1.5 \mathrm{E}-05$ \\
\hline $\mathrm{Pu}-242$ & $<1.59 \mathrm{E}-09$ & $<7.80 \mathrm{E}-11$ & $<1.04 \mathrm{E}-10$ & $<6.57 \mathrm{E}-11$ & $<8.25 \mathrm{E}-11$ & & DL & $4.6 \mathrm{E}-07$ \\
\hline $\mathrm{Pu}-244$ & $<7.39 \mathrm{E}-12$ & $<3.63 \mathrm{E}-13$ & $<4.82 \mathrm{E}-13$ & $<3.06 \mathrm{E}-13$ & $<3.84 \mathrm{E}-13$ & & $\mathrm{DL}$ & $2.3 \mathrm{E}-09$ \\
\hline Am-241 & $<1.10 \mathrm{E}-08$ & $6.78 \mathrm{E}-07$ & $7.75 \mathrm{E}-07$ & $1.05 \mathrm{E}-06$ & 8.34E-07 & 1.93E-07 & 8.9 & $2.7 \mathrm{E}-04$ \\
\hline $\begin{array}{l}\text { Gross } \\
\text { alpha }\end{array}$ & $<2.98 \mathrm{E}-05$ & $<1.44 \mathrm{E}-05$ & $<1.49 \mathrm{E}-05$ & $<1.73 \mathrm{E}-05$ & $<1.55 \mathrm{E}-05$ & & MDA & NA \\
\hline Gross beta & $<6.79 \mathrm{E}-05$ & $2.44 \mathrm{E}-03$ & $2.65 \mathrm{E}-03$ & $3.23 \mathrm{E}-03$ & $2.78 \mathrm{E}-03$ & $4.06 E-04$ & 10.0 & NA \\
\hline Eu-154 & $<1.30 \mathrm{E}-08$ & $4.11 \mathrm{E}-07$ & $4.48 \mathrm{E}-07$ & $5.29 \mathrm{E}-07$ & $4.63 \mathrm{E}-07$ & $6.07 E-08$ & 5.0 & NA \\
\hline Eu-155 & $<2.59 \mathrm{E}-08$ & $<1.19 \mathrm{E}-07$ & $6.28 \mathrm{E}-08$ & $<1.40 \mathrm{E}-07$ & $\leq 1.07 \mathrm{E}-07$ & & MDA/22.3 & NA \\
\hline Sb-126 & $<9.49 \mathrm{E}-09$ & $<1.72 \mathrm{E}-08$ & $9.04 \mathrm{E}-09$ & $1.81 \mathrm{E}-08$ & $\leq 1.48 \mathrm{E}-08$ & & $\mathrm{MDA} / 10.7$ & NA \\
\hline $\mathrm{Cm}-242$ & $<9.15 \mathrm{E}-10$ & $1.44 \mathrm{E}-09$ & $3.13 \mathrm{E}-09$ & $1.76 \mathrm{E}-09$ & $2.11 \mathrm{E}-09$ & $9.01 E-10$ & 46.6 & NA \\
\hline $\mathrm{Cm}-244$ & $<3.72 \mathrm{E}-08$ & $1.47 \mathrm{E}-07$ & $3.03 \mathrm{E}-07$ & $1.89 \mathrm{E}-07$ & $2.13 \mathrm{E}-07$ & $8.10 \mathrm{E}-08$ & 19.6 & NA \\
\hline
\end{tabular}




\section{Appendix B-2}

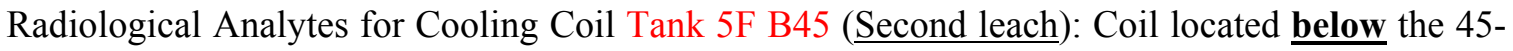
inches elevation of Tank 5F.

\begin{tabular}{|c|c|c|c|c|c|c|c|c|}
\hline Analytes & $\begin{array}{c}\text { Reference } \\
\text { Blank } \\
\text { Ci/ft } \mathbf{f t}^{2}\end{array}$ & $\begin{array}{l}\text { Run } 1 \\
\mathbf{C i} / \mathbf{f t}^{2}\end{array}$ & $\begin{array}{l}\operatorname{Run} 2 \\
\mathbf{C i} / \mathbf{f t}^{2}\end{array}$ & $\begin{array}{l}\operatorname{Run} 3 \\
\mathbf{C i} / \mathbf{f t}^{2}\end{array}$ & $\underset{\mathrm{Ci} / \mathrm{ft}^{2}}{\text { Average }}$ & Stdev. & $\begin{array}{c}\text { One Sigma } \\
\text { \%Uncertainty } \\
\text { Runs 1-3 }\end{array}$ & $\begin{array}{c}\text { Target } \\
\text { Detection } \\
\mathbf{C i} / \mathbf{f t}^{2}\end{array}$ \\
\hline Co-60 & 1.64E-08 & $3.52 \mathrm{E}-07$ & $2.50 \mathrm{E}-07$ & $3.23 \mathrm{E}-07$ & 3.09E-07 & $5.27 E-08$ & 5.0 & $8.3 \mathrm{E}-06$ \\
\hline Sr-90 & $5.07 \mathrm{E}-05$ & $6.07 \mathrm{E}-04$ & 5.81E-04 & 4.63E-04 & $5.50 \mathrm{E}-04$ & $7.67 \mathrm{E}-05$ & 6.5 & $5.9 \mathrm{E}-02$ \\
\hline Cs-137 & $2.37 \mathrm{E}-06$ & $7.75 \mathrm{E}-05$ & $7.39 \mathrm{E}-05$ & $5.20 \mathrm{E}-05$ & $6.78 \mathrm{E}-05$ & $1.38 E-05$ & 5.0 & $4.2 \mathrm{E}-03$ \\
\hline U-233 & $<1.05 \mathrm{E}-08$ & $<2.27 \mathrm{E}-09$ & $<8.59 \mathrm{E}-09$ & $<1.64 \mathrm{E}-09$ & $<4.17 \mathrm{E}-09$ & & DL & $1.1 \mathrm{E}-07$ \\
\hline U-234 & $<6.77 \mathrm{E}-09$ & $<1.46 \mathrm{E}-09$ & $<5.54 \mathrm{E}-09$ & $<1.05 \mathrm{E}-09$ & $<2.68 \mathrm{E}-09$ & & $\mathrm{DL}$ & $7.8 \mathrm{E}-08$ \\
\hline U-235 & $<2.35 \mathrm{E}-12$ & $1.06 \mathrm{E}-11$ & $9.52 \mathrm{E}-12$ & $9.02 \mathrm{E}-12$ & $9.73 \mathrm{E}-12$ & $8.25 E-13$ & 20.0 & $2.7 \mathrm{E}-09$ \\
\hline U-236 & $<7.03 \mathrm{E}-11$ & $<1.52 \mathrm{E}-11$ & $<5.77 \mathrm{E}-11$ & $1.32 \mathrm{E}-11$ & $\leq 2.87 \mathrm{E}-11$ & & DL & 4.6E-07 \\
\hline U-238 & $<1.08 \mathrm{E}-11$ & $2.68 \mathrm{E}-10$ & $2.36 \mathrm{E}-10$ & $2.27 \mathrm{E}-10$ & $2.44 \mathrm{E}-10$ & $2.16 E-11$ & 20.0 & $7.8 \mathrm{E}-08$ \\
\hline Np-237 & $<5.68 \mathrm{E}-09$ & $<2.86 \mathrm{E}-09$ & $<2.70 \mathrm{E}-09$ & $<2.69 \mathrm{E}-09$ & $<2.75 \mathrm{E}-09$ & & 20.0 & $1.1 \mathrm{E}-07$ \\
\hline $\mathrm{Pu}-238$ & 2.09E-08 & $2.18 \mathrm{E}-07$ & $1.05 \mathrm{E}-07$ & $1.40 \mathrm{E}-07$ & $1.54 \mathrm{E}-07$ & $5.78 \mathrm{E}-08$ & 7.0 & $6.5 \mathrm{E}-05$ \\
\hline Pu-239 & $1.99 \mathrm{E}-08$ & 4.24E-07 & $2.50 \mathrm{E}-07$ & $2.66 \mathrm{E}-07$ & $3.13 \mathrm{E}-07$ & $9.60 E-08$ & 20.0 & $1.5 \mathrm{E}-05$ \\
\hline $\mathrm{Pu}-240$ & $1.01 \mathrm{E}-08$ & $1.09 \mathrm{E}-07$ & $6.55 \mathrm{E}-08$ & $7.11 \mathrm{E}-08$ & $8.19 \mathrm{E}-08$ & $2.38 E-08$ & 20.0 & $3.3 \mathrm{E}-06$ \\
\hline $\mathrm{Pu}-241$ & $<4.01 \mathrm{E}-06$ & $<2.02 \mathrm{E}-06$ & $<3.78 \mathrm{E}-06$ & $<2.08 \mathrm{E}-06$ & $<2.63 \mathrm{E}-06$ & & MDA & $1.5 \mathrm{E}-05$ \\
\hline Pu-242 & $<1.46 \mathrm{E}-10$ & $<1.37 \mathrm{E}-10$ & $<9.54 \mathrm{E}-11$ & $<7.92 \mathrm{E}-11$ & $<1.04 \mathrm{E}-10$ & & $\mathrm{DL}$ & $4.6 \mathrm{E}-07$ \\
\hline $\mathrm{Pu}-244$ & $<6.81 \mathrm{E}-13$ & $<6.38 \mathrm{E}-13$ & $<4.43 \mathrm{E}-13$ & $<3.68 \mathrm{E}-13$ & $<4.83 \mathrm{E}-13$ & & DL & $2.3 \mathrm{E}-09$ \\
\hline Am-241 & $1.08 \mathrm{E}-07$ & 1.40E-06 & $1.15 \mathrm{E}-06$ & $1.07 \mathrm{E}-06$ & $1.20 \mathrm{E}-06$ & $1.72 \mathrm{E}-07$ & 5.0 & $2.7 \mathrm{E}-04$ \\
\hline $\begin{array}{l}\text { Gross } \\
\text { alpha }\end{array}$ & $<3.43 \mathrm{E}-05$ & $<1.70 \mathrm{E}-05$ & $<1.53 \mathrm{E}-05$ & $<1.41 \mathrm{E}-05$ & $<1.54 \mathrm{E}-05$ & & MDA & NA \\
\hline $\begin{array}{l}\text { Gross } \\
\text { beta }\end{array}$ & $1.00 \mathrm{E}-04$ & $1.54 \mathrm{E}-03$ & $1.56 \mathrm{E}-03$ & $1.14 \mathrm{E}-03$ & $1.41 \mathrm{E}-03$ & 2.37E-04 & 11.0 & NA \\
\hline Sb-126 & $<1.12 \mathrm{E}-09$ & $6.22 \mathrm{E}-08$ & $1.98 \mathrm{E}-08$ & $4.08 \mathrm{E}-08$ & $4.09 \mathrm{E}-08$ & $2.12 E-08$ & 5.0 & NA \\
\hline Eu-154 & 4.74E-08 & $6.52 \mathrm{E}-07$ & $5.50 \mathrm{E}-07$ & $5.42 \mathrm{E}-07$ & 5.81E-07 & $6.15 E-08$ & 5.0 & NA \\
\hline Eu-155 & $7.54 \mathrm{E}-09$ & $7.27 \mathrm{E}-08$ & $7.39 \mathrm{E}-08$ & $1.65 \mathrm{E}-07$ & $1.04 \mathrm{E}-07$ & $5.31 E-08$ & 13.3 & NA \\
\hline Cm-242 & $<2.08 \mathrm{E}-08$ & $<6.20 \mathrm{E}-09$ & $9.26 \mathrm{E}-09$ & $<2.07 \mathrm{E}-08$ & $\leq 1.20 \mathrm{E}-08$ & & MDA/45.5 & NA \\
\hline Cm-244 & $<5.67 \mathrm{E}-08$ & $6.17 \mathrm{E}-07$ & $5.71 \mathrm{E}-07$ & $8.89 \mathrm{E}-07$ & $6.92 \mathrm{E}-07$ & $1.72 \mathrm{E}-07$ & 10.8 & NA \\
\hline
\end{tabular}




\section{Distribution:}
A. B. Barnes, 999-W
D. A. Crowley, 773-43A
A. P. Fellinger, 773-41A
S. D. Fink, 773-A
B. J. Giddings, 786-5A
C. C. Herman, 999-W
S. L. Marra, 773-A
A. M. Murray, 773-A
F. M. Pennebaker, 773-42A
W. R. Wilmarth, 773-A
L. N. Oji, 773-42A
D. P. DiPrete, $773-41 \mathrm{~A}$
S. H. Reboul, 773-A
R. C. Jolly, Jr., 241-109F
W. B. Dean, 705-1C
W. L. Isom, Jr., 704-26F
C. E. Duffey, 704-61H
A. W. Wiggins, 704-60H
R. Young, 773-A, B-152
M. Mahoney, 705-1C 